\title{
2nd Portuguese Young Chemists Meeting
}

De 21 a 23 de Abril de 2010, realizouse, na Universidade de Aveiro, o $2^{\text {nd }}$ Portuguese Young Chemists Meeting 2PYCheM. Este Encontro contou com a presença efectiva de 240 Químicos Portugueses, maioritariamente jovens investigadores. Além do elevado número de participantes, o 2PYCheM foi também responsável por reunir jovens investigadores de diversos departamentos das Universidades de Aveiro (UA), Coimbra (UC), Lisboa (UL), Porto (UP), Minho (UMinho), Beira Interior (UBI), Nova de Lisboa (UNL), Trás-os-Montes e Alto Douro (UTAD), Madeira (UMA), Évora (UE), Santiago de Compostela (USC), Técnica de Yildiz (Istambul) e dos Institutos Politécnico de Viseu (IPV), Superior Técnico (IST) e Tecnológico e Nuclear (ITN).

Com o sucesso desta segunda edição, o PYCheM deu um grande passo na sua consolidação como um evento nacional de renome que esperamos que possa ser aguardado, de dois em dois anos, com grande expectativa. Este encontro envolveu a participação de quatro oradores de reconhecido mérito, sendo eles o Prof. Kurt Wüthrich (Prémio Nobel da Química 2002, ETH-Zürich e The Scripps-California) - "The protein universe: structural biology in the postgenomic era", Prof. Carlos Pascoal Neto (Universidade de Aveiro) - "New materials from renewable resources", Prof. José Moura (Universidade Nova de Lisboa) - "Coordination chemistry working for biology: enzymatic activity mastered by altering metal environment" e Prof. Manuela Ribeiro Carrott (Universidade de Évora) - "Templated mesoporous materials: expectations, facts and challenges". No entanto, o enfoque principal foi dado a jovens químicos que tiveram uma excelente oportunidade para apresentarem e discutirem o seu trabalho científico em 131 comunicações em painel e 23 comunicações orais das mais diversas áreas da Química. Foram premiadas duas comunicações orais - Konstantin Luzyanin (IST) e Cláudia Rocha (UA) e 2 comunicações em painel - Carlos Lima (UP) e Ângela Pereira (UA).
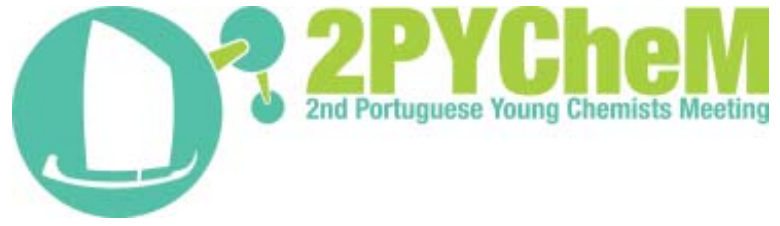

Para além da indispensável vertente científica, o 2PYCheM desenvolveu também algumas actividades de carácter social, dando a possibilidade aos seus participantes de conhecerem os aspectos mais típicos que caracterizam a região de Aveiro. Salientamos também a participação de um elevado número de instituições académicas e industriais, às quais expressamos o nosso profundo agradecimento pelo apoio prestado à organização. Estas instituições foram, sem dúvida, parte integrante do êxito do Encontro. Tento em conta o enorme sucesso desta iniciativa do Grupo de Químicos

Jovens da Sociedade Portuguesa de Química, é com agrado que anunciamos a sua continuidade. A próxima edição, a ser organizada por um grupo de investigadores do Departamento de Química da Universidade do Porto, irá realizar-se em 2012, em data a anunciar. Até lá, estejam atentos ao sítio www.spq.pt/gqj onde poderão estar actualizados acerca das actividades desenvolvidas no âmbito do Grupo de Químicos Jovens.

VC, MS, SS

(Pela Comissão Organizadora do 2PYCheM)

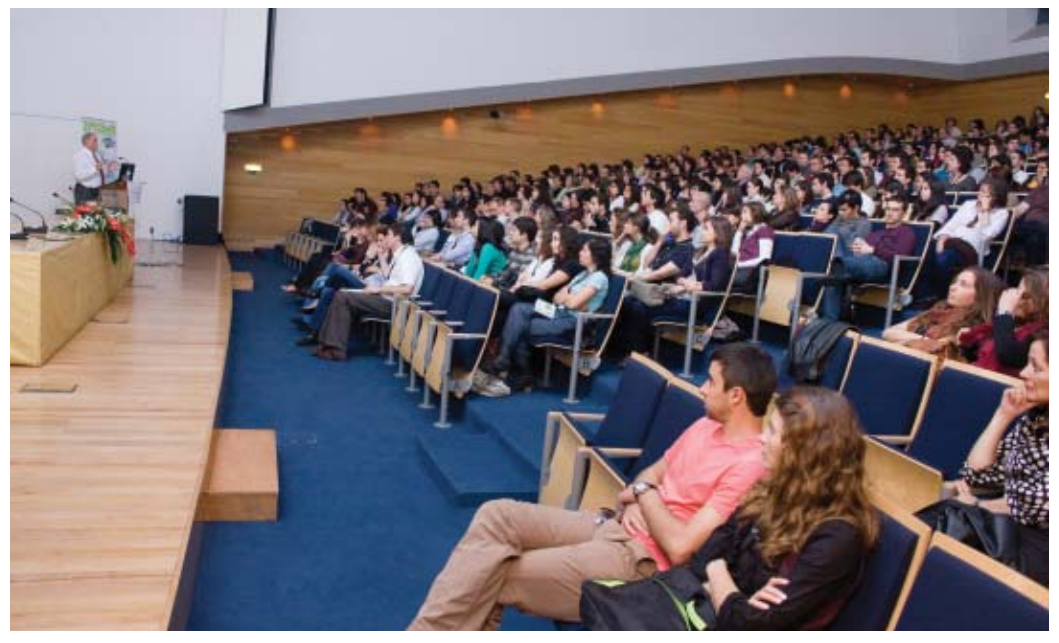

Palestra do Prof. Kurt Wüthrich

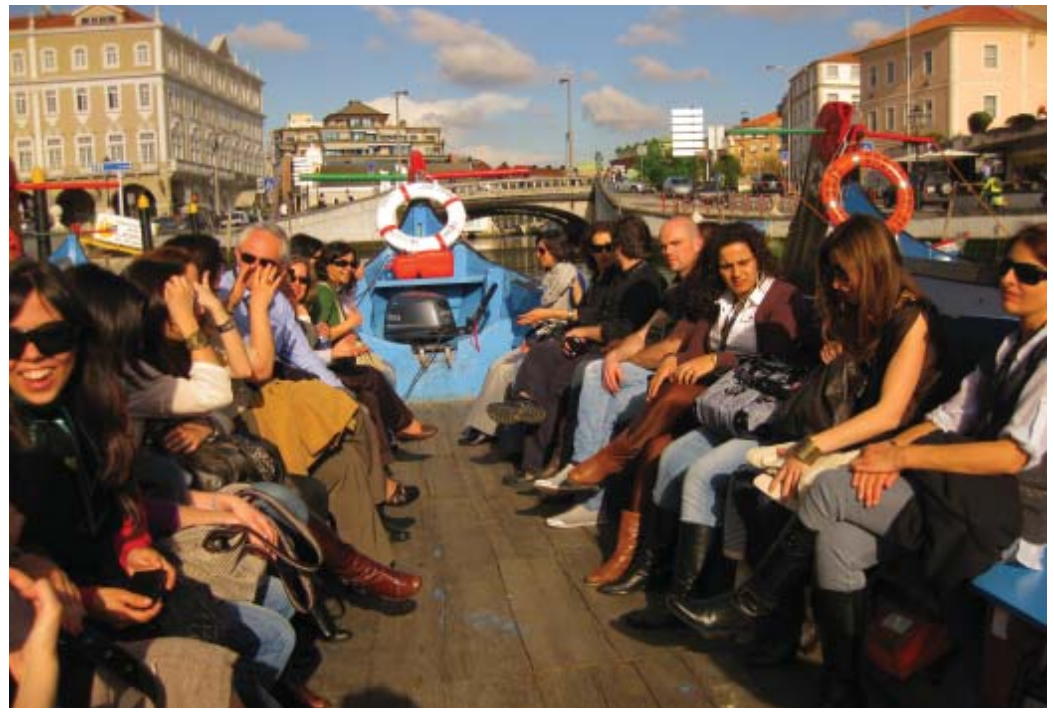

Passeio de Moliceiro pelos canais da Ria de Aveiro 